\title{
PENGARUH KEPEMIMPINAN TRANSFORMASIONAL DAN BUDAYA ORGANISASI TERHADAP KOMITMEN ORGANISASI DAN KINERJA KARYAWAN PADA PT. SASJAM RIRI DI KABUPATEN GIANYAR
}

\author{
Ni Kadek Winie Kaori Intan Mahkota ${ }^{1}$ \\ Desak Ketut Sintaasih ${ }^{2}$ \\ Agoes Ganesha Rahyuda ${ }^{3}$
}

\author{
${ }^{1}$ Fakultas Ekonomi dan Bisnis Universitas Udayana (Unud), Bali, Indonesia \\ Email contact: winiekaori@yahoo.com \\ ${ }^{2}$ Fakultas Ekonomi dan Bisnis Universitas Udayana (Unud), Bali, Indonesia \\ ${ }^{3}$ Fakultas Ekonomi dan Bisnis Universitas Udayana (Unud), Bali, Indonesia
}

\begin{abstract}
ABSTRAK
Kinerja karyawan merupakan hal penting yang harus diperhatikan, karena berkaitan erat dengan kelangsungan hidup perusahaan. Tujuan penelitian ini adalah untuk menganalisis pengaruh kepemimpinan transformasional dan budaya organisasi terhadap komitmen organisasi dan kinerja karyawan. Penelitian dilakukan pada PT. Sasjam Riri di Kabupaten Gianyar. Populasi dalam penelitian ini adalah seluruh karyawan perusahaan berjumlah 83 orang.Teknik penentuan sampel menggunakan metode sensus atau sampel jenuh, yaitu dengan mengambil seluruh populasi sebagai sampel penelitian. Instrumen penelitian menggunakan kuisioner dan teknik analisis data yang digunakan adalah analisis jalur (path). Hasil penelitian menyatakan bahwa, komitmen berperan sebagai variabel mediasi hubungan antara Kepemimpinan Transformasional atau Budaya Organisasi dan Kinerja Karyawan dan berpengaruh baik secara simultan maupun secara parsial pada peningkatan kinerja karyawan pada PT. Sasjam Riri Gianyar. Implikasi dari penelitian ini adalah Kinerja Karyawan PT. Sasjam Riri meningkat apabila pemimpin menunjukkan Gaya Kepemimpinan Transformasional dan karyawan berada pada Budaya Organisasi yang disepakati oleh seluruh karyawan, ke dua hal tersebut mampu memberikan peningkatan Kinerja Karyawan melalui penguatan Komitmen Organisasi.

Kata kunci : Kepemimpinan Transformasional, Budaya Organisasi, Komitmen Organisasi dan Kinerja Karyawan
\end{abstract}

\begin{abstract}
The impact of employee's performance is one of the important value thing that needs a specific concern, regarding it's connection to the company's long term journey. The main purpose of this research is to analyze the effect of transformational leadership and organization culture towards organizational commitment and employee's performance. This research is conducted in PT. Sasjam Riri in Gianyar regentcy. The research itself is taking all the member of its employee in the company, which is consist of 83 people. Sampling technique that used in this research is census method, which is also involving all population of all research sample. The research's instrumentt is using questionnaire and path analysis as based for data analysis technique. The result of the research states that, the tranformasional leadership and organization culture into its commitment would give a good effect simulataneously and also partially to the improvement of the employee's performance. The result also approved that the commitment is making a variable relation between transformational leadership or organization culture and its eemployee's performance, inside the entity. The implication of this research is that the employee's performance of PT. Sasjam Riri's getting better if the leader shows a transformational leadership style and the employees follows the oorganization culture, that has been agreed by all the employees, therefore it can give an improvement to the employee's performance throughout the organization's commitment strengthening.
\end{abstract}

Keyword: Transformational Leadership, Organization Culture, Organization Commitment and Employee's Performance. 
Ni Kadek Winie Kaori Intan Mahkota, dan Agoes Ganesha Rahyuda. Pengaruh ...

\section{PENDAHULUAN}

Usaha Mikro, Kecil, dan Menengah (UMKM) telah menjadi tulang punggung perekonomian Indonesia. Sejak tahun 1998, dimana UMKM tetap eksis ditengah banyak usaha besar yang tumbang karena dihantam krisis, sampai saat ini UMKM mampu menopang kelanjutan perekonomian Indonesia (Harian Kompas,2014). Di Bali, UMKM juga berperan dalam memperluas lapangan kerja dan memberikan pelayanan ekonomi secara luas kepada masyarakat, peningkatan pendapatan masyarakat, mendorong pertumbuhan ekonomi, dan secara tidak langsung berperan dalam mewujudkan stabilitas nasional (Suluh Indonesia, 2015) Perhatian pemerintah pun cukup besar terhadap UMKM di Indonesia, salah satunya dengan membantu UMKM mengadakan pameran dagang di beberapa negara serta mengadakan pertemuan gathering antara pelaku usaha dengan pembeli, pemerintah juga telah memberikan subsidi kepada UMKM melalui Kredit Usaha Rakyat (KUR) bekerja sama dengan beberapa perbankan yang telah membantu menggulirkan bantuan modal usaha kepada masyarakat dengan bunga yang murah tanpa agunan (Kementrian Koperasi, dan Usaha Kecil Menengah, 2015).

Tentu kesuksesan UMKM tidak lepas dari kualitas yang memadai dalam membantu pemilik usaha dalam mengelola usaha, keahlian dalam memasarkan hasil produksi, menjaga kualitas barang yang diproduksi hingga kemampuan mengelola keuangan perusahaan. Namun data menunjukkan bahwa jumlah UMKM yang besar dari segi kuantitasnya masih belum didukung oleh perkembangan yang memadai dari segi kualitasnya sehingga kinerja UMKM masih tertinggal. Ketertinggalan tersebut disebabkan oleh kekurang mampuan UMKM dalam bidang manajemen, penguasaan teknologi, dan pemasaran. (Bappenas, 2011)

Mahkota (2017:5) penelitiannya pada salah satu usaha dupa aromatherapi di Bali, menyatakan bahwa, target produksi yang diberikan kepada karyawan melenceng rata-rata 6,5 persen bulan, serta tingkat produk cacat (reject) sebesar rata-rata 4,1 persen per bulan dari toleransi sebesar 2 persen. Jika kinerja buruk ini dibiarkan maka akan berdampak pada kinerja dan juga siklus hidup UMKM tersebut (Mulyadi, 2005). Terdapat beberapa faktor faktor krusial yang harus diperhatikan oleh enterpreneur saat mengelola karyawannya dalam rangka mecapai 
tingkat kinerja yang optimal, seperti misalnya gaya kepemimpinan, menurut Handoko (2013:85) kepemimpinan adalah suatu kegiatan dan kemampuan dari seseorang atau beberapa orang atas dasar kepercayaan yang diberikan kepadanya untuk menggerakan dan memengaruhi pihak lain. Siagian (2005:150) mengemukakan bahwa, kepemimpinan adalah kemampuan seseorang untuk mempengaruhi orang lain (para bawahannya) sedemikian rupa sehingga orang lain itu mau melakukan kehendak pemimpin meskipun secara pribadi hal itu mungkin tidak disenanginya. Menurut Yukl (2009:112 ) kepemimpinan berkaitan dengan proses yang disengaja dari seseorang untuk menekankan pengaruhnya yang kuat terhadap orang lain untuk membimbing, membuat struktur, menfasilitasi aktivitas dan hubungan didalam kelompok atau organisasi.

Budaya organisasi merupakan sebuah konsep sebagai salah satu kunci keberhasilan suatu organisasi dalam mencapai tujuannya. Menurut Harvey dan Brown (2009:205) mendefinisikan budaya organisasi sebagai suatu sistem nilai dan kepercayaan bersama yang berinteraksi dengan orang - orang, struktur dan sistem suatu organisasi untuk menghasilkan norma - norma perilaku. Schein (2009:224), mendefinisikan budaya sebagai suatu pola dari asumsi dasar yang diciptakan, ditemukan, atau dikembangkan oleh kelompok tertentu saat belajar menghadapi masalah adaptasi eksternal dan integrasi internal yang telah berjalan cukup baik untuk dianggap valid, dan oleh karena itu, untuk diajarkan kepada anggota baru sebagai cara yang benar untuk berpersepsi, berpikir dan berperasaan sehubungan dengan masalah yang dihadapinya. Budaya organisasi adalah seperangkat asumsi atau sistem keyakinan, nilai-nilai dan norma yang dikembangkan dalam organisasi yang dijadikan pedoman tingkah laku bagi anggota - anggotanya untuk mengatasi masalah adaptasi eksternal dan integrasi internal (Mangkunegara, 2007:148).

Penelitian Borrill dan Dawson (2008), menemukan adanya hubungan positif dan signifikan antara kepemimpinan tim manajemen puncak dengan budaya organisasi. Menurut Wood (2011:184), budaya organisasi adalah sistem yang dipercayai dan nilai yang dikembangkan oleh organisasi dimana hal itu menuntun perilaku dari anggota organisasi itu sendiri, Budaya organisasi dan gaya kepemimpinan merupakan hal yang sangat penting dalam mengatur dan mengelola perjalanan organisasi. Gaya kepemimpinan adalah suatu cara yang dipergunakan 
Ni Kadek Winie Kaori Intan Mahkota, dan Agoes Ganesha Rahyuda. Pengaruh ...

oleh seorang pemimpin dalam mempengaruhi, mengarahkan, mendorong, dan mengendalikan karyawannya dalam rangka pencapaian tujuan organisasi secara efesien dan efektif (Modiani, 2012:116).

Menurut penelitian Bass (2012) menyatakan bahwa kepemimpinan transformasional merupakan gaya kepemimpinan yang sesuai untuk diterapkan pada konteks UMKM dalam rangka membantu karyawan meningkatkan kinerjanya. Iklim dan akibat yang diperoleh bawahan dari pemimpin transformasional adalah meningkatnya motivasi kerja, antusiasme, komitmen, kepuasan kerja, kesejahteraan dan kesehatan bawahan. Sedangkan menurut Yukl (2009) menyatakan bahwa, kepemimpinan transformasional sangat cocok diterapkan untuk usaha kecil dan menengah karena melalui dampaknya terhadap bagaimana pemimpin memperkuat sikap saling kerjasama dan mempercayai, kemanjuran diri secara kolektif dan pembelajaran tim. Para pemimpin transformasional membuat para pengikutnya menjadi lebih menyadari kepentingan dan nilai dari pekerjaan serta membujuk pengikut untuk tidak mendahulukan kepentingan pribadi diatas kepentingan organisasi. Karakteristik budaya organisasi menurut Timothy (2008:256) mengemukakan, bahwa budaya organisasi memiliki karakteristik kunci yang dijunjung tinggi oleh organisasi. Karakteristik tersebut secara keseseluruhan merupakan hakikat budaya. Sedangkan karakteristik budaya organisasi menurut Robbins (2008:208) menyatakan bahwa untuk menilai kualitas budaya organisasi suatu perusahaan dapat dilihat dari sepuluh faktor utama, yaitu : inisiatif terhadap individu, toleransi terhadap tindakan resiko, pengarahan, integrasi, dukungan manajemen, kontrol, identitas, sistem imbalan, toleransi terhadap publik, dan pola komunikasi. Karakteristik karyawan yang sesuai dengan kebutuhan organisasi mampu meningkatkan kinerja karyawan karena dengan adanya pengarahan dimaksudkan sejauh mana suatu organisasi/perusahaan dapat menciptakan dengan jelas sasaran dan harapan yang diinginkan. Sasaran dan harapan tersebut jelas tercantum dalam visi, misi dan tujuan organisasi. Kondisi ini dapat berpengaruh terhadap peningkatan kinerja organisasi/perusahaan (Robbins, 2008). Sedangkan menurut Timothy (2008), karakteristik karyawan yang sesuai dengan kebutuhan organisasi yang mampu meningkatkan kinerja karyawan karena adanya sistem imbalan dimaksudkan sejauh mana alokasi imbalan (kenaikan gaji, 
promosi dan sebagainya) didasarkan atas prestasi kerja karyawan, bukan didasarkan atas senioritas, sikap pilih kasih, atau kedekatan hubungan keluarga.

Secara tidak langsung, baik kepemimpinan transformasional maupun budaya organisasi mampu meningkatkan kinerja melalui peningkatan komitmen karyawan. Penelitian Jui (2009) hasil temuannya menyatakan bahwa, ada korelasi kepemimpinan memiliki dampak pada organisasi, departemen, tim, serta positif antara kepemimpinan dengan komitmen organisasi dan kinerja karyawan. Penelitian yang dilakukan oleh Huei (2012) juga menunjukkan bahwa, kepemimpinan transformasional yang baik memberikan pengaruh positif dan signifikan terhadap komitmen organisasi, perilaku interaksi memiliki pengaruh yang signifikan terhadap kinerja karyawan. Komitmen karyawan pada organisasi juga akan meningkat jika budaya organisasi mampu mendekatkan karakteristik karyawan tersebut dengan apa yang diharapkan organisasi. Brown (2013) menguji pengaruh perilaku kepemimpinan yang berorientasi pada hubungan dan tugas terhadap komitmen organisasi. Temuannya menunjukkan bahwa perilaku kepemimpinan yang berorientasi pada hubungan yang meliputi membangun kepercayaan terhadap bawahan, selalu memberikan inspirasi dan menjadi panutan karyawan dalam segala hal, mengerti dan paham dengan visi perusahaan, mendorong kreativitas karyawan dalam mengembangkan ide-ide yang disarankan, pada penelitian ini diketahui ada hubungan dan pengaruh yang positif dan signifikan antara perilaku kepemimpinan dengan komitmen afektif karyawan.

Penelitian menurut Acar (2012) menyatakan bahwa semakin tinggi komitmen karyawan pada organisasi, pekerjaan maupun tanggung jawabnya maka kinerja karyawan tersebut juga meningkat . Penelitian yang dilakukan Chen (2009) menguji tentang pengaruh komitmen organisasi dan gaya kepemimpinan di perusahaan textile di China dimana hasil penelitiannya menyatakan adanya pengaruh signifikan positif antara gaya kepemimpinan manager perusahaan terhadap komitmen organisasi. Beberapa penelitian ini menunjukkan peran variabel komitmen organisasi sebagai variabel mediasi pada hubungan antara kepemimpinan transformasional atau budaya organisasi dan kinerja karyawan. Sayangnya, peran ini jarang dieksplorasi, utamanya pada konteks UMKM di Bali. 
Ni Kadek Winie Kaori Intan Mahkota, dan Agoes Ganesha Rahyuda. Pengaruh ...

Tujuan penelitian ini adalah untuk menguji pengaruh kepemimpinan transformasional dan budaya organisasi terhadap kinerja karyawan dan juga menguji peran mediasi dari variabel komitmen organisasi pada hubungan antara kepemimpinan transformasional atau budaya organisasi dan kinerja karyawan. Model penelitian yang dibangun pada penelitian ini akan diuji pada konteks UMKM di Bali, karena rendahnya kualitas sumber daya manusia yang mengelola UMKM di Bali (BPS, 2016), kurangnya pembinaan dan pelatihan kepemimpinan untuk pelaku UMKM di Bali dan pemilik usaha tidak begitu paham dengan menerapkan budaya organisasi di perusahaannya (Dinas Koperasi dan UMKM prov. Bali, 2016).

\section{KAJIAN PUSTAKA DAN HIPOTESIS}

Kinerja merupakan tingkat pencapaian hasil atas pelaksanaan tugas tertentu. Istilah kinerja berasal dari job performance atau actual performance (prestasi kerja atau prestasi sesungguhnya yang dicapai oleh seseorang), atau juga hasil kerja secara kualitas dan kuantitas yang ingin dicapai oleh seorang pegawai dalam melaksanakan tugasnya sesuai dengan tanggung jawab yang diberikan kepadanya. (Mangkunegara, 2007 : 158). Dampak positif kinerja adalah hasil kerja yang dapat dicapai seseorang atau sekelompok orang dalam suatu organisasi, sesuai dengan wewenang dan tanggung jawab masing-masing dalam upaya mencapai tujuan organisasi bersangkutan secara legal, tidak melanggar hukum dan sesuai dengan moral maupun etika (Sedarmayanti, 2007:69), kinerja juga berdampak positif untuk menganalisis dan membantu memperbaiki masalah-masalah dalam pencapaian tujuan perusahaan. Menurut Furtwengler, (2002:136) Indikator kineja karyawan yang berdasarkan kepuasan pelanggan atas pelayanan, produk dan jasa yang bernilai lebih bagi pelanggan yang dapat diuraikan sebagai berikut :

a. Kecepatan, dalam hal ini adalah kemampuan setiap karyawan dalam memberikan pelayanan terhadap para pelanggan atau konsumen langsung baik retail atau pun grosiran yang sesuai Standard Operating Procedure (SOP). 
b. Kualitas adalah kecepatan dalam memberikan pelayanan, tanpa kualitas adalah sia-sia. Pelayanan yang cepat dan berkualitas dapat membuat para pelanggan merasa puas, dapat menghemat waktu dan biaya.

c. Layanan adalah setiap layanan yang diberikan oleh karyawan sesuai dengan jenis pekerjaannya yang diberikan pada semua pelanggan baik internal maupun eksternal akan sangat mendukung kecepatan dan kualitas pelayanan.

d. Nilai adalah setiap pelanggan menginginkan nilai atas layanan. Layanan yang cepat dan berkualitas sesuai dengan harapan pelanggan.

\section{Hubungan Komitmen Organisasi dan Kinerja Karyawan}

Robbins dan Judge (2008:253) mendefinisikan komitmen organisasi sebagai suatu keadaan dimana seseorang individu memihak organisasi serta tujuantujuan dan keinginan nya untuk mempertahankan keanggotaannya dalam organisasi. Sedangkan Mathis dan Jackson (2010) mendefinisikan komitmen organisasi sebagai derajat dimana karyawan percaya dan mau menerima tujuan-tuj Menurut Allen and Meyer dalam Robbins (2008), mengemukakan tiga indikator komitmen karyawan yaitu sebagai berikut :

1) Komitmen Afektif (affective commitment)

Komitmen afektif adalah keterikatan emosional, identifikasi serta keterlibatan seseorang karyawan pada suatu organisasi. Komitmen afektif seseorang akan menjadi lebih kuat bila pengalaman nya dalam suatu organisasi konsisten dengan harapan-harapan dan memuaskan kebutuhan dasarnya dan sebaliknya.

2. Komitmen berkelanjutan (continuance commitment)

Komitmen berkelanjutan merupakan komitmen karyawan yang didasarkan pada pertimbangan apa yang harus dikorbankan bila meninggalkan organisasi atau kerugian yang akan diperoleh jika tidak melanjutkan pekerjaan dalam organisasi. Tindakan meninggalkan organisasi menjadi sesuatu yang beresiko tinggi karena karyawan merasa takut akan kehilangan sumbangan yang mereka tanamkan pada organisasi itu dan menyadari bahwa mereka tak mungkin mencari gantinya.

3. Komitmen karyawan normatif (normative commitment)

Komitmen normatif merupakan komitmen karyawan terhadap organisasinya karena kewajiban nya untuk bertahan dalam organisasi untuk alasan-alasan 
Ni Kadek Winie Kaori Intan Mahkota, dan Agoes Ganesha Rahyuda. Pengaruh ...

moral atau etis, atau dengan kata lain keyakinan yang dimiliki karyawan tentang tanggung jawabnya terhadap organisasi.

Penelitian yang dilakukan oleh AL-Ahmadi (2009) menemukan bahwa, kinerja berkorelasi positif dengan komitmen organisasional, kinerja karyawan, variabel pribadi dan professional. Dalam penelitian ini tersebut diungkap bahwa kepemimpinan dan komitmen punya pengaruh kuat terhadap kinerja karyawan. Komitmen organisasional menunjukkan suatu daya dari seseorang dalam mengidentifikasikan keterlibatannya dalam suatu bagian organisasi (Mowday, 2012). Komitmen karyawan dibangun atas dasar kepercayaan pekerja atas nilainilai organisasi, kerelaan pekerja membantu mewujudkan tujuan organisasi dan loyalitas untuk tetap menjadi anggota organisasi. Oleh karena itu, komitmen karywan akan menimbulkan rasa ikut memiliki (sense of belonging) bagi pekerja terhadap organisasi. Jika pekerja merasa jiwanya terikat dengan nilai-nilai organisasional yang ada maka dia akan merasa senang dalam bekerja, sehingga kinerjanya dapat meningkat.

Meyer et al. (2013) menguji hubungan antara kinerja manajer tingkat atas dengan komitmen affective dan komitmen continuance pada perusahaan jasa makanan. Hasil penelitiannya menyatakan bahwa komitmen affective berkorelasi secara positif dengan kinerja, sedangkan komitmen continuance berkorelasi secara negatif dengan kinerja. Somers (2015) mengemukakan bahwa, komitmen organisasional (affective dan continuance) tidak berpengaruh terhadap kinerja. Siders et al. (2011) menyatakan bahwa, komitmen internal foci berhubungan dengan kinerja untuk reward secara organisasional. Berdasarkan atas kajian teori dan kajian empiris, maka dapat dirumuskan hipotesis sebagai berikut.

Hipotesis 1 : Komitmen karyawan pada organisasi mampu meningkatkan kinerja karyawan

\section{Hubungan Kepemimpinan Transformasional, Komitmen Organisasi dan Kinerja Karyawan}

Kepemimpinan transformasional merupakan pemimpin yang menginspirasi para pengikut untuk melampaui kepentingan pribadi mereka dan yang mampu membawa dampak mendalam dan luar biasa pada para pengikut. Menurut Burns dalam Safaria (2009:82) kepemimpinan transformasional dicirikan sebagai 
pemimpin yang berfokus pada pencapaian perubahan nilai-nilai, kepercayaan, sikap, perilaku, emosional dan kebutuhan bawahan menuju perubahan yang lebih baik di masa depan. Pemimpin transformasional merupakan seorang agen perubahan yang berusaha keras melakukan transformasi ulang organisasi secara menyeluruh sehingga organisasi bisa mencapai kinerja yang lebih maksimal di masa depan. Modiani (2012:105) yang mengemukakan kepemimpinan transformasional merupakan kemampuan untuk memberikan inspirasi dan memotivasi para pengikutnya untuk mencapai hasil-hasil yang lebih besar daripada yang direncanakan secara orisinil. Ada beberapa indikator kepemimpinan transformasional menurut Robbins (2010:158)

1) Karisma (Charisma)

Karisma dianggap sebagai kombinasi dari pesona dan daya tarik pribadi yang berkontribusi terhadap kemampuan luar biasa untuk membuat orang lain mendukung visi dan juga mempromosikannya dengan bersemangat. Pemimpin karismatik adalah pemimpin yang mewujudkan atmosfir motivasi atas dasar komitmen dan identitas emosional pada visi, filosofi, dan gaya mereka dalam diri bawahanya

2) Inspirasi Motivasi (Motivation Inspirational)

Inspiratif Motivasi inspiratif menggambarkan pemimpin bergairah dalam mengkomunikasikan masa depan organisasi yang idealis. Pemimpin menggunakan komunikasi verbal atau penggunaan simbol-simbol yang ditujukan untuk memacu semangat bawahan. Pemimpin memotivasi bawahan akan arti penting visi dan misi organisasi sehingga seluruh bawahannya terdorong untuk memiliki visi yang sama. Kesamaan visi ini memacu bawahan untuk bekerja sama mencapai tujuan jangka panjang dengan optimis. Sehingga pemimpin tidak saja membangkitkan semangat individu tapi juga semangat tim.

3) Stimulasi Intelektual (Intelectual Stimulation)

Intelektual Stimulasi menggambarkan pemimpin mampu mendorong karyawan untuk memecahkan masalah lama dengan cara yang baru. Pemimpin berupaya mendorong perhatian dan kesadaran bawahan akan permasalahan yang dihadapi. Pimpinan kemudian berusaha mengembangkan kemampuan 
Ni Kadek Winie Kaori Intan Mahkota, dan Agoes Ganesha Rahyuda. Pengaruh ...

bawahan untuk menyelesaikan permasalahan dengan pendekatan-pendekatan atau perspektif baru.

4) Perhatian kepada Individu (Individualized consideration)

Merupakan pemahaman dan perhatian pemimpin pada potensi dan kemampuan yang dimiliki oleh setiap karyawannya. Perhatian yang individual menggambarkan bahwa pimpinan selalu memperhatikan karyawannya, memperlakukan karyawan secara individual, melatih dan menasehati. Pemimpin mengajak karyawan untuk jeli melihat kemampuan orang lain. Pemimpin memfokuskan karyawan untuk mengembangkan kelebihan pribadi.

Penelitian yang dilakukan oleh Huei (2012) menunjukkan bahwa, kepemimpinan yang baik memberikan pengaruh positif dan signifikan terhadap komitmen organisasi, perilaku interaksi memiliki pengaruh yang signifikan terhadap kinerja karyawan. Brown (2013) menguji pengaruh perilaku kepemimpinan yang berorientasi pada hubungan dan tugas terhadap komitmen organisasi. Temuannya menunjukkan bahwa perilaku kepemimpinan yang berorientasi pada hubungan yang meliputi membangun kepercayaan terhadap bawahan, selalu memberikan inspirasi dan menjadi panutan karyawan dalam segala hal, mengerti dan paham dengan visi perusahaan, mendorong kreativitas karyawan dalam mengembangkan ide-ide yang disarankan, pada penelitian ini diketahui ada hubungan dan pengaruh yang positif dan signifikan antara perilaku kepemimpinan dengan komitmen afektif karyawan. Penelitian yang dilakukan Chen (2009) menguji tentang pengaruh komitmen organisasi dan gaya kepemimpinan di perusahaan textile di China diman hasil penelitiannya menyatakan adanya pengaruh signifikan positif antara gaya kepemimpinan manager perusahaan terhadap komitmen organisasi. Penelitian menurut Acar (2012) yang menguji 344 orang karyawan pada perusahaan industri logistik di Turkey menemukakan bahwa, gaya kepemimpinan sangat penting untuk menguatkan komitmen organisasi di perusahaan tersebut. Berdasarkan atas kajian teori dan kajian empiris yang telah diuraikan maka:

Hipotesis 2 : Penerapan kepemimpinan transformasional dalam organisasi mampu meningkatkan komitmen karyawan pada organisasi 
Sukanada (2010) hasil penelitiannya menunjukkan bahwa variable kepemimpinan berpengaruh positif dan signifikan secara langsung terhadap kinerja karyawan yang berarti bahwa hubungan yang positif, yaitu semakin baik kepemimpinan yang ada maka semakin baik pula kinerja karyawan dan sebaliknya. Penelitian lain yang meneliti tentang faktor-faktor yang mempengaruhi kinerja karyawan yang dilakukan oleh mawar (2007) menyimpulkan bahwa, kepemimpinan berpengaruh positif dan signifikan terhadap kinerja pegawai PT Askes (Persero) Kantor Cabang Denpasar. Penelitian yang dilakukan oleh Ben (2012) untuk mengetahui kepemimpinan di kalangan guru sekolah menengah Ilmu Pertanian dan kinerja pekerjaan mereka di negara Ibom Akwa. Hasil analis menunjukkan bahwa variable kepemimpinan seperti kreativitas, kemampuan dalam komunikasi, kemampuan dalam berhubungan antar manusia, kemampuan untuk mengambil keputusan, kesehatan, kebugaran dan kapasitas intelektual Ilmu Pertanian secara signifikan berhubungan dengan prestasi kerjanya. Faktor penting yang menentukan kinerja dan kemampuan beradaptasi dengan perubahan lingkungan menurut Bass et al. (2013) dan Locander et al. (2012) adalah faktor kepemimpinan. Kepemimpinan menggambarkan hubungan antara pemimpin dengan yang dipimpin dan bagaimana seorang pemimpin mengarahkan pengikutnya akan menentukan sejauh mana pengikutnya mencapai tujuan atau harapan pimpinan.

Hipotesis 3 : Penerapan kepemimpinan transformasional dalam organisasi mampu meningkatkan kinerja karyawan, baik secara langsung maupun tidak langsung melalui kinerja karyawan.

\section{Hubungan Budaya Organisasi, Komitmen Organisasi, dan Kinerja Karyawan}

Menurut Robbins (2008:106) budaya organisasi merupakan sistem makna bersama yang dianut oleh anggota-anggota yang membedakan suatu organisasi dari organisasi lain. Sistem makna bersama ini, bila diamati dengan lebih seksama, merupakan seperangkat karakteristik utama yang dihargai oleh suatu organisasi. Schein (2009:224), mendefinisikan budaya sebagai suatu pola dari asumsi dasar yang diciptakan, ditemukan, atau dikembangkan oleh kelompok tertentu saat belajar menghadapi masalah adaptasi eksternal dan integrasi internal yang telah 
Ni Kadek Winie Kaori Intan Mahkota, dan Agoes Ganesha Rahyuda. Pengaruh ...

berjalan cukup baik untuk dianggap valid, dan oleh karena itu, untuk diajarkan kepada anggota baru sebagai cara yang benar untuk berpersepsi, berpikir dan berperasaan sehubungan dengan masalah yang dihadapinya.

Budaya Organisasi kuat adalah suatu sistem nilai yang menjadi pegangan perusahaan beserta anggota yang terlibat, serta menjadi acuan untuk mengembalikan perilaku organisasi dan anggota organisasi dalam berinteraksi antar anggota organisasi lainnya, menurut Acar (2012) terdiri dari :

a. Keterlibatan (involvement), keterlibatan merupakan faktor kunci dalam pengaruh budaya organisasi, keterlibatan yang tinggi dari anggota organisasi berpengaruh terhadap kinerja perusahaan khususnya menyangkut manajemen, strategi perushaan dan struktur organisasi.

b. Konsistensi (consistency), menyangkut keyakinan, nilai-nilai, dan peraturanperaturan yang mempunyai pengaruh terhadap kinerja karyawan perusahaan.

c. Adaptabilitas (adaptibility), kemampuan untuk menyadari dan bereaksi pada lingkungan eksternal maupun internal perusahaan

d. Misi (Mission), penghayatan misi memberikan dua pengaruh besar pada fungsi perusahaan yaitu : suatu misi menunjukkan maksud dan arti serta alasan-alasan yang bersifat non ekonomi mengapa misi itu penting dilakukan, dan pengertian misi menentukan arah tujuan menjadi jelas, yang selanjutnya menentukan saluran kegiatan yang layak bagi organisasi dan para anggotanya

Acar (2012) meneliti bahwa, budaya organisasi berhubungan positif dengan tingkat komitmen organisasi. Jenis hirarki budaya organisasi adalah positif terkait tingkat komitmen organisasi. Moon (2010) dalam penelitiannya menunjukkan bahwa budaya organisasi yang diukur melalui kejelasan tujuan organisasi dan otonomi pekerjaan mempunyai pengaruh yang signifikan positif terhadap komitmen organisasi baik pada perusahaan swasta maupun perusahaan pemerintah. Sedangkan Lok dan Crawford (2009) menguji pengaruh budaya organisasional dan gaya kepemimpinan transformasional terhadap dan komitmen organisasional pada para manajer Australia dan Hongkong.

Hipotesis 4 : Budaya organisasi mampu meningkatkan komitmen karyawan, pada organisasi 
Kreitner dan Kinicki (2010) menyatakan bahwa, budaya organisasi sebagai perekat perusahaan melalui nilai-nilai yang ditaati, mempunyai pengaruh positif dan signifikan terhadap kinerja karyawan. Setiap perusahaan pasti memiliki makna sendiri terhadap kata budaya itu sendiri, yang meliputi : identitas, ideologi, etos, budaya, pola perilaku, eksistensi, aturan, filosofi, tujuan. spirit, sumber informasi, gaya dan visi perusahaan. Jadi dapat disimpulkan bahwa budaya organisasi (corporate culture) adalah sebagai aturan main yang ada dalam perusahaan yang menjadi pegangan bagi sumber daya manusia perusahaan dalam menjalankan kewajiban dan nilai-nilai untuk berperilaku dalam perusahaan.

Flamholtz dan Narasimhan (2015) meneliti tentang pengaruh perbedaan elemen-elemen budaya terhadap kinerja keuangan, dengan menggunakan 702 responden pada perusahaan industri di US. Hasil penelitiannya menyatakan bahwa beberapa elemen budaya organisasi mempunyai pengaruh yang berbeda pada kinerja keuangan perusahaan. Henri (2006) mengadakan penelitian tentang budaya organisasi dan sistem pengukuran kinerja. Temuannya menyatakan bahwa, sistem pengukuran kinerja memfokuskan pada organisasi, mendukung strategi pembuatan keputusan serta melegitimasi kekuasaan top manager. Budaya organisasi adalah komponen yang sangat penting dalam meningkatkan kinerja karyawan, namun demikian agar kinerja karyawan meningkat maka harus ditingkatkan pula motivasi kerjanya. Budaya organisasi pada sisi internal karyawan akan memberikan sugesti kepada semua perilaku yang diusulkan oleh organisasi agar dapat dikerjakan, penyelesaian yang sukses, dan akan memberikan keuntungan pada karyawan itu sendiri. Akibatnya karyawan akan memiliki kepercayaan pada diri sendiri, kemandirian dan mengagumi dirinya sendiri. Sifat-sifat ini akan dapat meningkatkan harapan karyawan agar kinerjanya semakin meningkat. Berdasarkan uraian dan hasil penelitian tersebut di atas, maka dirumuskan hipotesis penelitian: Hipotesis 5 : Budaya organisasi mampu meningkatkan kinerja karyawan, baik secara langsung maupun tidak langsung melalui kinerja karyawan.

\section{METODE PENELITIAN}

Penelitian ini dilakukan di PT. Sasjam Riri yang berlokasi di Graha Kaori Group jl. Raya Mas no. 86x Desa Mas, Kecamatan Ubud, Kabupaten Gianyar. 
Ni Kadek Winie Kaori Intan Mahkota, dan Agoes Ganesha Rahyuda. Pengaruh ...

Populasi dalam penelitian ini adalah karyawan PT. Sasjam Riri yang berjumlah 84 orang tersebar pada 5 unit usaha di Kaori Group. Teknik pengambilan sampel dilakukan dengan cara sensus atau sampel jenuh, yaitu teknik sampling yang dilakukan dengan cara mengambil seluruh populasi sebagai sampel penelitian. Sampel penelitian ini sejumlah 83 orang karena General Manager tidak diikutsertakan dengan alasan penelitian ini meneliti tentang kepemimpinan transformasional.

Metode yang dipergunakan untuk mengumpulkan data dalam penelitian ini adalah

1) Kuesioner, yaitu teknik pengumpulan data yang dilakukan dengan cara memberikan sejumlah pertanyaan tertulis secara terstruktur kepada responden penelitian berkaitan dengan tanggapannya terhadap berbagai variabel yang diteliti dalam penelitian ini.

2) Wawancara, pengumpulan data dengan cara melakukan tanya jawab secara mendalam kepada responden penelitian untuk memperoleh data yang lebih akurat dan lengkap karena menyangkut penjelasam lebih lanjut dari kuesioner yang telah dibagikan kepada responden. Instrumen dalam penelitian ini adalah kuesioner dengan skala Likert 1-5, dimana angka 1 menunjukkan sangat tidak setuju (STS) sampai dengan angka 5 menunjukkan sangat tidak setuju (SS).

\section{Uji Validitas Instrumen}

Kuesioner dinyatakan valid jika mampu mengungkapkan sesuatu yang diukur oleh kuesionar tersebut. Pengujian validitas dapat dilakukan dengan mengguna korelasi product moment. Jika koefisien korelasi sama atau lebih besar dari angka 0,3 $(\geq 0,3)$ maka butir instrumen dinyatakan valid, dan tidak valid apabila koefisien lebih kecil dari 0,3 $(<0,3)$ Hipotesis diuji dengan t-test pada masing-masing jalur pengaruh langsung secara parsial. Rekapitulasi hasil analisis jalur sebagai dasar pengujian hipotesis disajikan pada Tabel 1

\section{Uji Reliabilitas Instrumen}

Uji reliabilitas ini merupakan bentuk uji kualitas data yang menunjukkan stabilitas dan konsistensi dari instrumen untuk mengukur konstruk/variabel. Nilai batas yang 
diperkenankan untuk menilai atau menguji apakah setiap variabel dapat dipercaya, handal dan akurat dipergunakan formula Cronbach's Alpha. Suatu kuesioner dikatakan reliabel atau handal jika jawaban responden atas pertanyaan adalah konsisten atau stabil dari waktu ke waktu. Instrumen dinyatakan reliabel apabila nilai alpha cronbach $\geq 0,60$, jika alpha cronbach $<0,60$ maka dikatakan tidak variabel.

Tabel 1

Rekapitulasi Uji Validitas

\begin{tabular}{|c|c|c|c|}
\hline Variabel & oefisien Korelasi & Signifikansi & Keterangan \\
\hline \multicolumn{4}{|c|}{ Gaya Kepemimpinan } \\
\hline Kharisma $\left(\mathrm{X}_{1.1}\right)$ & 0,911 & 0,000 & Valid \\
\hline Motivasi $\left(\mathrm{X}_{1} .2\right)$ & 0,924 & 0,000 & Valid \\
\hline Stimulasi $\left(\mathrm{X}_{1} .3\right)$ & 0,859 & 0,000 & Valid \\
\hline $\begin{array}{c}\text { Kemampuan Individu } \\
\left(\mathrm{X}_{1} .4\right)\end{array}$ & 0.858 & 0,000 & Valid \\
\hline \multicolumn{4}{|l|}{ Budaya Organisasi } \\
\hline Konsistensi $\left(\mathrm{X}_{2.2}\right)$ & 0,798 & 0,000 & Valid \\
\hline Adaptabilitas $\left(\mathrm{X}_{2} .3\right)$ & 0,893 & 0,000 & Valid \\
\hline $\operatorname{Misi}\left(\mathrm{X}_{2} .4\right)$ & 0,891 & 0,000 & Valid \\
\hline \multicolumn{4}{|l|}{ Komitmen } \\
\hline Komitmen Afektif $\left(Y_{1} .1\right)$ & 0,892 & 0,000 & Valid \\
\hline $\begin{array}{l}\text { Komitmen berkelanjutan } \\
\qquad\left(\mathrm{Y}_{1.2)}\right.\end{array}$ & 0,853 & 0,000 & Valid \\
\hline $\begin{array}{c}\text { Komitmen Normatif } \\
\left(\mathrm{Y}_{1} .3\right)\end{array}$ & 0,913 & 0,000 & Valid \\
\hline \multicolumn{4}{|l|}{ Kinerja } \\
\hline Kecepatan $\left(\mathrm{Y}_{2.1}\right)$ & 0,836 & 0,000 & Valid \\
\hline Kualitas $\left(\mathrm{Y}_{2} .2\right)$ & 0,847 & 0,000 & Valid \\
\hline Layanan $\left(\mathrm{Y}_{2} .3\right)$ & 0,800 & 0,000 & Valid \\
\hline Nilai $\left(\mathrm{Y}_{2.4)}\right.$ & 0,892 & 0,000 & Valid \\
\hline
\end{tabular}

Sumber: lampiran 2, 2016

Tabel 2

Rekapitulasi Uji Reliabilitas

\begin{tabular}{ccc}
\hline Variabel & Cronbach's Alpha & Keterangan \\
\hline $\mathrm{X}_{1}$ & 0,924 & Reliabel \\
\hline
\end{tabular}


Ni Kadek Winie Kaori Intan Mahkota, dan Agoes Ganesha Rahyuda. Pengaruh ...

\begin{tabular}{lll}
\hline $\mathrm{X}_{2}$ & 0,892 & Reliabel \\
$\mathrm{Y}_{1}$ & 0,858 & Reliabel \\
$\mathrm{Y}_{2}$ & 0,863 & Reliabel \\
\hline
\end{tabular}

Sumber: lampiran 3, 2016

\section{Teknik Analisis Data}

Dalam menganalisis model hubungan antar variabel penelitian dilakukan dengan menggunakan teknik Analisis Jalur ( Path Analysis). Sebelum dilakukan analisis jalur, terlebih dahulu dilakukan analisis deskriptif dan analisis faktor konfirmatori.

\section{HASIL PENILITIAN DAN PEMBAHASAN}

Kepemimpinan transformasional yang dimaksud dalam hal ini merupakan proses mengarahkan dan mempengaruhi aktivitas-aktivitas yang ada hubungannya dengan pekerjaan para anggota kelompok. Kepemimpinan transformasional diukur dengan empat dimensi, yaitu karisma, motivasi, stimulasi dan kemampuan individu. Hasil jawaban responden untuk variabel kepemimpinan transformasional secara rinci disajikan pada Tabel 3

Dari data yang tersaji dalam Tabel 3 menunjukkan bahwa kepemimpinan transformasional di PT. Sasjam Riri termasuk dalam kriteria baik. Kondisi tersebut ditunjukkan dengan nilai rata- rata skor keseluruhan variabel kepemimpinan transformasional adalah 4,14. Dari 4 dimensi kepemimpinan transformasional yaitu karisma, motivasi, stimulasi dan kemampuan individu, ternyata yang memiliki rata-rata skor tertinggi adalah stimulasi dengan skor 4,48. Hal ini diartikan bahwa pemimpin di perusahaan selalu mengembangkan kemampuan karyawan dalam memahami permasalahan. Kepemimpinan transformasional yang baik juga ditunjukkan dari dimensi karisma, dengan skor 4,35 yang menggambarkan tentang pemimpin diperusahaan selalu menjadi panutan kebanggaan karyawan, dan yang perlu mendapatkan perhatian adalah dimensi kemampuan individu, yang skor terendah dalam tabel yang disajikan adalah 3,87 yang menunjukkan bahwa pemimpin di perusahaan selalu berupaya memahami kemampuan yang dimiliki oleh karyawan untuk mengarahkan kemampuan terbaik setiap karyawan. 
Tabel 3

Deskripsi Variabel Kepemimpinan Transformasional $\left(\mathbf{X}_{1}\right)$

PT. Sasjam Riri di Kabupaten Gianyar

\begin{tabular}{|c|c|c|c|c|c|c|c|c|}
\hline \multirow[t]{2}{*}{ No } & \multirow[t]{2}{*}{ Indikator Variabel } & \multicolumn{5}{|c|}{$\begin{array}{c}\text { Frekuensi Jawaban } \\
\text { Responden }\end{array}$} & \multirow{2}{*}{$\begin{array}{l}\text { Rata- } \\
\text { rata } \\
\text { skor }\end{array}$} & \multirow[t]{2}{*}{ Kete- rangan } \\
\hline & & STS & TS & $\mathrm{CS}$ & $\mathrm{S}$ & $\mathrm{SS}$ & & \\
\hline 1 & $\begin{array}{l}\text { Pemimpin di perusahaan } \\
\text { selalu menjadi panutan } \\
\text { kebanggaan karyawan }\end{array}$ & 2 & 4 & 10 & 14 & 53 & 4,35 & $\begin{array}{l}\text { Sangat } \\
\text { baik }\end{array}$ \\
\hline 2 & $\begin{array}{l}\text { Pemimpin selalu memberikan } \\
\text { inspirasi kepada karyawan } \\
\text { untuk memusatkan perhatian } \\
\text { pada tujuan bersama }\end{array}$ & 0 & 5 & 8 & 62 & 8 & 3,88 & baik \\
\hline 3 & $\begin{array}{l}\text { Pemimpin di perusahaan } \\
\text { selalu berupaya } \\
\text { mengembangkan kemampuan } \\
\text { karyawan dalam memahami } \\
\text { permasalahan }\end{array}$ & 0 & 4 & 6 & 19 & 54 & 4,48 & Sangat baik \\
\hline 4 & $\begin{array}{l}\text { Pemimpin di perusahaan } \\
\text { selalu berupaya memahami } \\
\text { kemampuan yang dimiliki } \\
\text { oleh karyawan untuk } \\
\text { mengarahkan kemampuan } \\
\text { terbaik setiap karyawan }\end{array}$ & 2 & 5 & 5 & 61 & 10 & 3,87 & baik \\
\hline & $\begin{array}{l}\text { Kepemimpinan } \\
\text { Transformasional }\end{array}$ & & & & & & 4,14 & baik \\
\hline
\end{tabular}

Sumber : Lampiran 2, 2016

\section{Deskripsi Variabel Budaya Organisasi $\left(\mathrm{X}_{2}\right)$}

Variabel budaya organisasi yang merupakan variabel terikat dalam penelitian ini diukur dengan empat dimensi yaitu keterlibatan (involment), konsistensi (consistency), adaptabilitas (adaptibility), dan misi (mision). Dari hasil penelitian dapat diketahui jawaban responden atas pernyataan tersebut tersaji dalam Tabel 1.4 berikut.

Dengan menyimak data pada Tabel 4, nampak bahwa budaya organisasi karyawan PT. Sasjam Riri tergolong baik. Budaya organisasi ini ditunjukkan dari nilai rata-rata skor variabel sebesar 3,89. Dari 4 dimensi yang mengukur budaya organisasi ternyata dimensi adaptibility memiliki skor tertinggi $(4,43)$, hal tersebut dapat diartikan bahwa PT. Sasjam Riri dapat beradaptasi sesuai perkembangan yang terjadi di masyarakat, dimana budaya organisasi diikuti oleh dimensi consistency $(3,96)$ dimana karyawan selalu mendapatkan peringatan apabila 
Ni Kadek Winie Kaori Intan Mahkota, dan Agoes Ganesha Rahyuda. Pengaruh ...

melanggar aturan perusahaan supaya tidak mengulangi kesalahan yang sama untuk kedua kalinya .

\section{Tabel 4}

Deskripsi variabel Budaya Organisasi $\left(\mathbf{X}_{2}\right)$ Karyawan

PT.Sasjam Riri di Kabupaten Gianyar.

\begin{tabular}{|c|c|c|c|c|c|c|c|c|}
\hline \multirow[b]{2}{*}{ No } & \multirow[b]{2}{*}{ Indikator } & \multicolumn{5}{|c|}{ Frekuensi jawaban responden } & \multicolumn{2}{|l|}{ Rata- } \\
\hline & & STS & $\mathrm{TS}$ & CS & S & SS & $\begin{array}{l}\text { Rata } \\
\text { skor }\end{array}$ & $\begin{array}{l}\text { Kete- } \\
\text { rangan }\end{array}$ \\
\hline 1 & $\begin{array}{l}\text { Adanya kesempatan untuk } \\
\text { menyampaikan ide pada setiap } \\
\text { pertemuan di perusahaan ini }\end{array}$ & 0 & 2 & 4 & 25 & 52 & 3,33 & Sedang \\
\hline 2 & $\begin{array}{l}\text { Mendapat peringatan apabila } \\
\text { melanggar aturan perusahaan }\end{array}$ & 0 & 1 & 5 & 73 & 4 & 3,96 & Baik \\
\hline 3 & $\begin{array}{l}\text { Perusahaan ini dapat beradaptasi } \\
\text { dengan perkembangan yang } \\
\text { terjadi di masyarakat }\end{array}$ & 0 & 1 & 9 & 26 & 47 & 4,43 & $\begin{array}{l}\text { Sangat } \\
\text { baik }\end{array}$ \\
\hline 4 & $\begin{array}{l}\text { Memahami tujuan jangka panjang } \\
\text { perusahaan ini dengan jelas }\end{array}$ & 0 & 3 & 14 & 59 & 7 & 3,84 & Baik \\
\hline & Budaya & rganis & & & & & 3,89 & Baik \\
\hline
\end{tabular}

Sumber : Lampiran 2, 2016

\section{Deskripsi Variabel Komitmen Organisasi $\left(\mathrm{Y}_{1}\right)$}

Variabel komitmen organisasi yang merupakan variabel terikat dalam penelitian ini diukur dengan tiga butir pernyataan. Dari hasil penelitian dapat diketahui jawaban responden atas pernyataan tersebut tersaji dalam Tabel 5 berikut

Tabel 5

Deskripsi Variabel Komitmen Organisasi (Y1) Karyawan PT . Sasjam Riri di Kabupaten Gianyar.

\begin{tabular}{llllllllll}
\hline & & \multicolumn{3}{c}{ Frekuensi jawaban responden } & Rata- & \\
No & Indikator & STS & TS & CS & S & SS & $\begin{array}{c}\text { Rata } \\
\text { skor }\end{array}$ & $\begin{array}{c}\text { Kete- } \\
\text { rangan }\end{array}$ \\
\hline 1 & $\begin{array}{l}\text { Merasa terikat secara emosional } \\
\text { dengan perusahaan ini }\end{array}$ & 1 & 4 & 8 & 24 & 46 & 4,33 & $\begin{array}{c}\text { Sangat } \\
\text { Tinggi }\end{array}$
\end{tabular}


2 Tidak ada alasan bagi saya untuk meninggalkan perusahaan ini, walaupun ada tawaran pekerjaan yang lebih baik di perusahaan lain

3 Merasa rugi jika meninggalkan perusahaan ini

Komitmen Organisasi

3,46 Tinggi

4,13 Tinggi

3,97 Tinggi

Sumber : Lampiran 2, 2016

Dengan menyimak data pada Tabel 5, nampak bahwa komitmen organisasi pada PT. Sasjam Riri di Kabupaten Gianyar tergolong tinggi. Komitmen ini ditunjukkan dari nilai rata-rata skor variabel komitmen organisasi sebesar 3,97. Dari tiga dimensi yang mengukur komitmen organisasional ternyata dimensi affective commitment memiliki skor tertinggi (4,33), dimana karyawan merasa terikat secara emosional dengan perusahaan ini, diikuti oleh dimensi continuance commitment $(4,13)$ yang menyatakan dimana karyawan merasa rugi jika meninggalkan perusahaan PT. Sasjam Riri dan yang perlu mendapatkan perhatian adalah pada dimensi normative commitment $(3,46)$ karena sebagian para karyawan ada yang memiliki persepsi akan memilih perusahaan lain apabila ada tawaran yang lebih baik.

\section{Deskripsi Variabel Kinerja Karyawan}

Kinerja karyawan (Y2) dalam penelitian ini adalah hasil kerja yang dicapai oleh karyawan PT. Sasjam Riri sesuai dengan kewenangan dan tugas serta tanggung jawab masing-masing pada perusahaan. Kinerja karyawan dalam hal ini bisa dibagi menjadi 4 dimensi yaitu kecepatan, kualitas, layanan dan nilai. Adapun hasil statistik deskriptif variabel kinerja karyawan disajikan pada Tabel 6

Tabel 6

Deskripsi Variabel Kinerja Karyawan ( $\left.\mathrm{Y}_{2}\right)$ PT. Sasjam Riri di Kabupaten Gianyar

\begin{tabular}{cccccccccc} 
& & \multicolumn{1}{c}{ Frekuensi jawaban responden } & & Rata- & Kete- \\
No & Indikator & STS & TS & CS & S & SS & rata & rangan \\
& & & & & & skor & \\
& & & & & & & & &
\end{tabular}


Ni Kadek Winie Kaori Intan Mahkota, dan Agoes Ganesha Rahyuda. Pengaruh ...

\begin{tabular}{|c|c|c|c|c|c|c|c|c|}
\hline 1 & $\begin{array}{l}\text { Bisa menyelesaikan pekerjaan } \\
\text { sesuai dengan target waktu yang } \\
\text { telah ditentukan perusahaan }\end{array}$ & 0 & 2 & 5 & 22 & 54 & 4,54 & $\begin{array}{c}\text { Sangat } \\
\text { Baik }\end{array}$ \\
\hline 2 & $\begin{array}{l}\text { Sering membuat kesalahan } \\
\text { dalam menyelesaikan tugas yang } \\
\text { menjadi tanggung jawab masing- } \\
\text { masing karyawan }(\mathrm{R})\end{array}$ & 25 & 45 & 3 & 7 & 3 & 3,61 & Baik \\
\hline 3 & $\begin{array}{l}\text { Memberikan layanan sesuai } \\
\text { dengan jenis pekerjaan saya }\end{array}$ & 0 & 1 & 6 & 24 & 52 & 4,53 & $\begin{array}{c}\text { Sangat } \\
\text { Baik }\end{array}$ \\
\hline 4 & $\begin{array}{l}\text { Jarang mendapat keluhan dari } \\
\text { pelanggan }\end{array}$ & 0 & 6 & 7 & 67 & 3 & 3,81 & Baik \\
\hline & \multicolumn{6}{|c|}{ Kinerja Karyawan } & 4,12 & Baik \\
\hline
\end{tabular}

Sumber : Lampiran 2, 2016

Hasil perhitungan pada Tabel 6 menunjukkan persentase jawaban responden terhadap $\left(\mathrm{Y}_{2}\right)$ kinerja karyawan PT. Sasjam Riri di Gianyar, sebagian besar karyawan sudah menunjukkan kinerja yang baik. Secara keseluruhan kinerja karyawan dapat dikatakan baik dengan skor rata-rata mencapai angka 4,12, kinerja karyawan dari masing-masing indikator seperti kecepatan, kualitas, layanan, nilai semuanya menunjukkan rata-rata di atas tiga (3), dengan rata-rata tertinggi ditunjukkan oleh indikator no. 1 mencapai angka 4,54, yang menyatakan bahwa karyawan bisa menyelesaikan pekerjaan sesuai dengan target waktu yang telah ditentukan perusahaan. Sedangkan indikator kinerja karyawan yang menunjukkan skor terendah ada pada indikator no.2, dimana karyawan sering membuat kesalahan dalam yang menjadi tanggung jawab masing-masing karyawan.

Model dikatakan fit jika didukung oleh data empirik. Uji goodness of fit dapat dilihat pada hasil analisis jalur seperti tersaji pada Tabel 5.11 dan Tabel 5.12 Goodness of Fit model struktural pada analisis jalur berupa nilai Koefision Determinasi Total $\left(\mathrm{R}^{2} \mathrm{M}\right)$, dihitung berdasarkan nilai $\mathrm{R}^{2}$ masing - masing variabel endogen. Untuk variabel Komitmen Organisasional $\left(\mathrm{Y}_{1}\right)$, nilai $\mathrm{R}^{2}=0,743$ dan untuk variabel Kinerja karyawan $\left(\mathrm{Y}_{2}\right)$ diperoleh $\mathrm{R}^{2}=0.807$

Nilai predictive-relevance diperoleh dengan perhitungan sebagai berikut:

$$
R_{M}^{2}=1-\left(1-\mathrm{R}_{1}^{2}\right)\left(1-\mathrm{R}_{2}^{2}\right)
$$




$$
\begin{aligned}
R_{M}^{2} & =1-(1-0,743)(1-0,807) \\
& =1-(0,257)(0,193)=1-0,0049601 \\
R_{M}^{2} & =0,950399
\end{aligned}
$$

Dari hasil perhitungan, diperoleh nilai $R_{M}^{2}=0,950399$ atau 95,04\%, yang memiliki arti bahwa 95,04\% data empirik dapat menjelaskan model, atau model dikatakan baik. Dengan demikian, model layak untuk memberikan penjelasan dan pengujian hipotesis.

\section{Hasil Pengujian Hipotesis}

Hipotesis diuji dengan dengan t-test pada masing-masing jalur pengaruh langsung secara parsial. Rekapitulasi hasil analisis jalur sebagai dasar pengujian hipotesis disajikan pada Tabel 7

\section{Rekapitulasi Hubungan antar Variabel}

\begin{tabular}{ccccc}
\hline \multicolumn{1}{c}{ Hubungan antar variabel } & $\begin{array}{c}\text { Koefisien } \\
\text { jalur } \\
\text { (standardized })\end{array}$ & $\begin{array}{c}\text { p- } \\
\text { value }\end{array}$ & keterangan \\
\hline $\begin{array}{c}\text { Kepemimpinan } \\
\text { Transformasional }\left(\mathrm{X}_{1}\right)\end{array}$ & Komitmen Organisasi $\left(\mathrm{Y}_{1}\right)$ & 0,419 & 0,000 & Signifikan \\
Budaya organisasi $\left(\mathrm{X}_{2}\right)$ & Komitmen Organisasi $\left(\mathrm{Y}_{1}\right)$ & 0,475 & 0,000 & Signifikan \\
$\begin{array}{c}\text { Kepemimpinan } \\
\text { Transformasional }\left(\mathrm{X}_{1}\right)\end{array}$ & Kinerja Karyawan $\left(\mathrm{Y}_{2}\right)$ & 0,244 & 0,023 & Signifikan \\
$\begin{array}{c}\text { Budaya organisasi }\left(\mathrm{X}_{2}\right) \\
\text { Komitmen Organisasi } \\
\left(\mathrm{Y}_{1}\right)\end{array}$ & Kinerja Karyawan $\left(\mathrm{Y}_{2}\right)$ & 0,461 & 0,000 & Signifikan \\
\hline Sumberja Karyawan $\left(\mathrm{Y}_{2}\right)$ & 0,242 & 0,015 & Signifikan \\
\hline
\end{tabular}

Hasil pengujian hipotesis jalur-jalur pengaruh langsung juga dapet dilihat pada Gambar 1 diagram jalur, sebagai berikut 
Ni Kadek Winie Kaori Intan Mahkota, dan Agoes Ganesha Rahyuda. Pengaruh ...

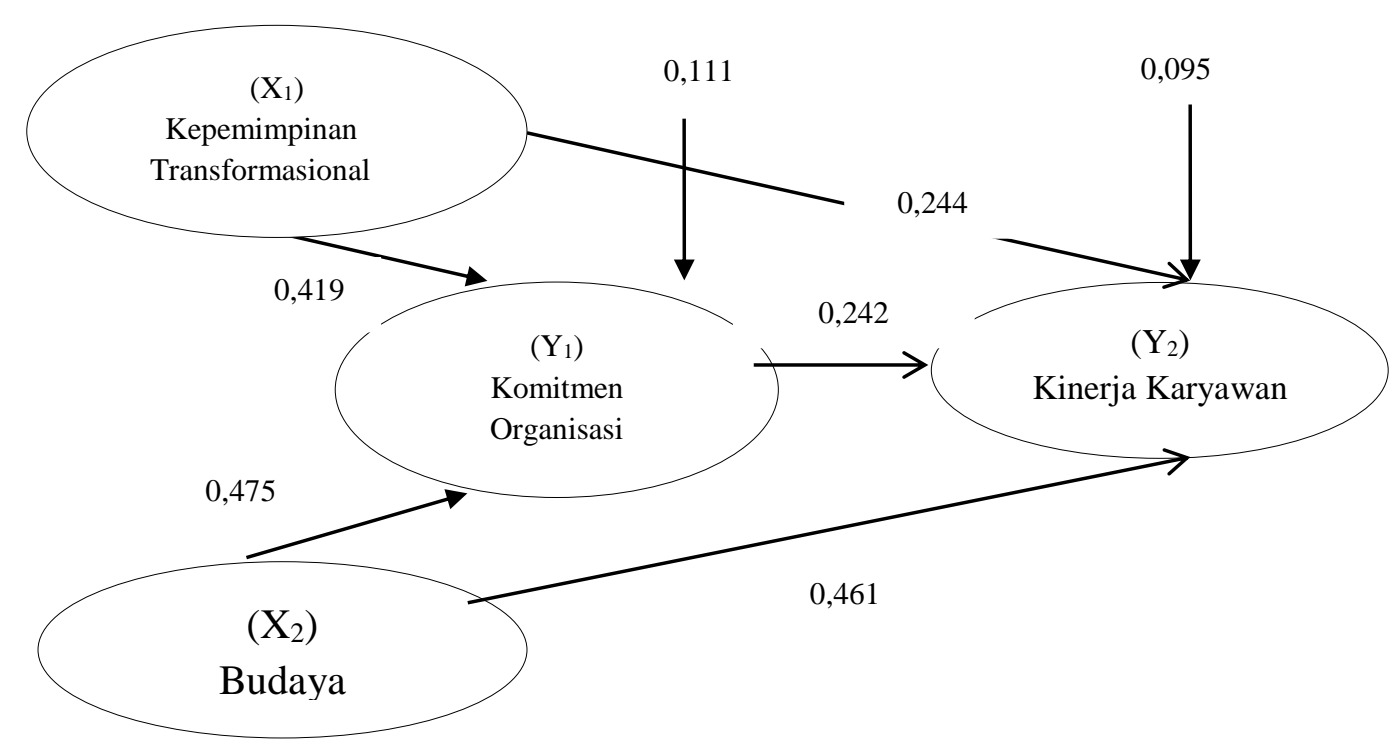

Gambar 1

\section{Diagram Jalur}

Berdasarkan hasil pengujian hipotesis secara statistik pada tabel 5.13, maka dapat dijelaskan hasil sebagai berikut.

1) Pengaruh Kepemimpinan Transformasional terhadap Komitmen Organisasi Data pada Tabel 5.13 menunjukkan bahwa, nilai koefisien jalur variabel kepemimpinan transformasional terhadap komitmen organisasi sebesar 0,419, dengan $p$. Value $=0,000$ lebih kecil dari $\alpha=0,05$ yang berarti signifikan. Koefisien jalur bertanda positif dapat diartikan semakin baik Kepemimpinan Transformasional $\left(\mathrm{X}_{1}\right)$, maka Komitmen Organisasinya $\left(\mathrm{Y}_{1}\right)$ semakin kuat bahwa, kepemimpinan transformasional berpengaruh positif dan signifikan terhadap komitmen organisasi, dengan demikian hipotesis 1 terdukung

2) Pengaruh Budaya Organisasi terhadap Komitmen Organisasi, berdasarkan Tabel 5.10 menunjukkan bahwa, nilai koefisien jalur pada variabel budaya organisasi terhadap komitmen organisasi adalah sebesar 0,475, dengan p.value $=0,000$ lebih kecil dari $\alpha=0,05$ yang berarti signifikan, Koefisien jalur bertanda positif , menunjukkkan bahwa semakin baik budaya organisasi perusahaan, maka komitmen organisasi semakin kuat. Secara singkat dapat dikatakan bahwa pencapaian penerapan budaya organisasi yang dijadikan sebagai norma dasar oleh karyawan dalam bekerja mampu meningkatkan komitmen organisasi pada perusahaan. Dengan demikian hipotesis 2, terdukung. 
3) Pengaruh Kepemimpinan Transformasional terhadap Kinerja Karyawan. Data pada Tabel 5.13 menunjukkan bahwa, nilai koefisien jalur variabel sebesar 0,244 , dengan p.value $=0,023$ lebih kecil dari $\alpha=0,05$ yang berarti signifikan. Koefisien jalur bertanda positif dapat diartikan bahwa, semakin baik gaya Kepemimpinan Transformasional yang diterapkan dalam perusahaan maka kinerja karyawan akan meningkat. Dikatakan bahwa pencapaian penerapan kepemimpinan transformasional dapat meningkatkan kinerja karyawan pada perusahaan. Dengan demikian hipotesis 3, terdukung

4) Pengaruh Budaya Organisasi terhadap Kinerja Karyawan. Berdasarkan hasil data pada Tabel 5.13 menunjukkan bahwa, nilai koefisien jalur variabel Budaya Organisasi terhadap Kinerja Karyawan sebesar 0,461, dengan p. Value $=0,000$ lebih kecil dari $\alpha=0,05$ yang berarti signifikan. Koefisien jalur bertanda positif dapat diartikan semakin baik Budaya Organisasi $\left(\mathrm{X}_{2}\right)$, maka Kinerja Karyawan $\left(\mathrm{Y}_{2}\right)$ semakin meningkat bahwa, Budaya Organisasi berpengaruh positif dan signifikan terhadap Kinerja Karyawan, dengan demikian hipotesis 4 terdukung

5) Pengaruh Komitmen Organisasi terhadap Kinerja Karyawan. hasil data pada Tabel 5.13 menunjukkan bahwa, nilai koefisien jalur variabel Budaya Organisasi terhadap Kinerja Karyawan sebesar 0,242, dengan p. Value =0,015 lebih kecil dari $\alpha=0,05$ yang berarti signifikan. Koefisien jalur bertanda positif dapat diartikan semakin kuat Komitmen Organisasi $\left(\mathrm{Y}_{1}\right)$, maka Kinerja Karyawan $\left(\mathrm{Y}_{2}\right)$ semakin meningkat bahwa, Komitmen Organisasi berpengaruh positif dan signifikan terhadap Kinerja Karyawan, dengan demikian hipotesis 5 terdukung

\section{Hasil Pengujian Mediasi}

1) Berdasarkan hasil nilai koefisien jalur dan tingkat signifikansinya seperti tersaji pada Tabel 5.13 maka hasil pengujian peran Komitmen Organisasi sebagai pemediasi diuraikan sebagai berikut. Pengaruh Kepemimpian Transformasional $\left(\mathrm{X}_{1}\right)$ terhadap Kinerja Karyawan $\left(\mathrm{Y}_{2}\right)$ pada model dengan tidak melibatkan variabel mediasi yaitu Komitmen Organisasi $\left(\mathrm{Y}_{1}\right)$ adalah signifikan; pengaruh Kepemimpinan Transformasional (X1) terhadap Komitmen Organisasional (Y1), sebagai pemediasi, adalah signifikan; pengaruh Komitmen Organisasional (Y1), 
Ni Kadek Winie Kaori Intan Mahkota, dan Agoes Ganesha Rahyuda. Pengaruh ...

terhadap Kinerja (Y2) adalah signifikan; dan Pengaruh Kepemimpinan Transformasional (X1) terhadap Kinerja Karyawan (Y2) pada model dengan melibatkan variable mediasi adalah signifikan, maka dapat dinyatakan bahwa Komitmen Organisasional memediasi sebagian (partial mediation) pengaruh Kepemimpinan Transformasional (X1) terhadap Kinerja Karyawan (Y2)

Peran pemediasi dianalisis lebih lanjut dengan uji Sobel, untuk mengetahui tingkat signifikansinya, dengan perhitungan sebagai berikut.

$$
\mathrm{S}_{\mathrm{ab}}=\sqrt{\left(b^{2}{s_{\mathrm{a}}^{2}}^{2}+a^{2} s_{\mathrm{b}}^{2}+{s_{\mathrm{a}}^{2}}^{2} \mathrm{~b}^{2}\right)}
$$

Dengan data yang disampaikan seperti pada Tabel 5.11 dan Tabel 5.12, diketahui $\mathrm{a}=0.419, \mathrm{Sa}=0.111, \mathrm{~b}=0.242, \mathrm{sb}=0.095$, maka dapat dihitung nilai $\mathrm{s}_{\mathrm{ab}}$ seperti berikut.

$$
\begin{aligned}
& S_{a b}=\sqrt{0,242^{2} x 0,111^{2}+0,419^{2} x 0,095^{2}+0,111^{2} x 0,095^{2}} \\
& S_{a b}=\sqrt{0,058 x 0,012+0,175 x 0,009+0,012 \times 0,009} \\
& S_{a b}=\sqrt{0,0006+0,0015+0,0001} S_{a b}=0,047
\end{aligned}
$$

Dengan mengetahui nilai $S_{a b}$, maka Nilai $Z_{\text {hitung dapat dicari dengan formulasi }}$ berikut: $Z_{\text {value }}=\mathrm{ab} / \mathrm{s}_{\mathrm{ab}}$

$$
\begin{gathered}
Z_{\text {hitung }}=\frac{a \times b}{\sqrt{b^{2} S_{a}^{2}+a^{2} S_{b}^{2}-S_{a}^{2} S_{b}^{2}}} \\
Z_{\text {hitung }}=0,419 \times 0,242 / 0,0475 \\
Z_{\text {hitung }}=0.1013 / 0,0475=2,1326
\end{gathered}
$$

Dari hasil perhitungan, ternyata $\mathrm{Z}$ value lebih besar dari nilai kritis 1,96 pada tingkat kesalahan 5\% $(\alpha=0,05)$, yang berarti pengujian signifikan. Dari hasil pengujian ini maka dapat disimpukan bahwa Komitmen Organisasi terbukti secara signifikan memediasi secara sebagian (partial mediation ) pengaruh Kepemimpinan Transformasional $\left(\mathrm{X}_{1}\right)$ terhadap Kinerja Karyawan $\left(\mathrm{Y}_{2}\right)$. Dengan demikian, hipotesis 6, yaitu Komitmen organisasional memediasi hubungan Kepemimpinan Transformasional dan Kinerja Karyawan, terdukung 
2) Peran Mediasi Komitmen Organisasi pada hubungan antara Budaya Organisasi terhadap Kinerja Karyawan. Berdasarkan hasil nilai koefisien jalur dan tingkat signifikansinya seperti tersaji pada Tabel 5.13 maka hasil pengujian peran Komitmen Organisasi sebagai pemediasi diuraikan sebagai berikut. Pengaruh Budaya Organisasi $\left(\mathrm{X}_{2}\right)$ terhadap Kinerja Karyawan $\left(\mathrm{Y}_{2}\right)$ pada model dengan tidak melibatkan variabel mediasi yaitu Komitmen Organisasi $\left(\mathrm{Y}_{1}\right)$ adalah signifikan; pengaruh Budaya Organisasi $\left(\mathrm{X}_{2}\right)$ terhadap Komitmen Organisasional ( $\left.\mathrm{Y}_{1}\right)$, sebagai pemediasi, adalah signifikan; pengaruh Komitmen Organisasional ( $\left.\mathrm{Y}_{1}\right)$, terhadap Kinerja $\left(\mathrm{Y}_{2}\right)$ adalah signifikan; dan Budaya Organisasi $\left(\mathrm{X}_{2}\right)$ terhadap Kinerja Karyawan $\left(\mathrm{Y}_{2}\right)$ pada model dengan melibatkan variable mediasi adalah signifikan, maka dapat dinyatakan bahwa Komitmen Organisasional memediasi sebagian (partial mediation) Budaya Organisasi $\left(\mathrm{X}_{2}\right)$ terhadap Kinerja Karyawan $\left(\mathrm{Y}_{2}\right)$. Pengujian signifikansi pengaruh tidak langsung pada model penelitian ini menggunakan uji Sobel.

$$
S_{a b}=\sqrt{b^{2} S_{a}^{2}+a^{2} S_{b}^{2}+S_{a}^{2} S_{b}^{2}}
$$

Dengan memasukkan nilai-nilai pada Tabel 5.11 dan Tabel 5.12 diketahui $\mathrm{a}=0,419, \quad \mathrm{~s}_{\mathrm{a}}=0,111, \mathrm{~b}=0,242, \mathrm{~s}_{\mathrm{b}}=0,095$. Berdasarkan nilai-nilai yang sudah diketahui, dapat dihitung nilai $S_{a b}$, sebagai berikut:

$$
\begin{aligned}
& S_{a b}=\sqrt{0,242^{2} x 0,111^{2}+0,419^{2} x 0,095^{2}+0,111^{2} x 0,095^{2}} \\
& S_{a b}=\sqrt{0,058 x 0,012+0,175 x 0,009+0,012 \times 0,009} \\
& S_{a b}=\sqrt{0,0006+0,0015+0,0001} S_{a b}=0,047
\end{aligned}
$$

Dengan mengetahui nilai $S_{a b}$, maka Nilai $Z_{\text {hitung dapat dicari dengan }}$ formulasi berikut:

$$
\begin{aligned}
& Z_{\text {hitung }}=\frac{a x b}{\sqrt{b^{2} S_{a}^{2}+a^{2} S_{b}{ }^{2}+S_{a}{ }^{2} S_{b}{ }^{2}}} \quad Z_{\text {hitung }}=\frac{0,475 \times 0,242}{0,047} \\
& Z_{\text {hitung }}=2,447
\end{aligned}
$$


Ni Kadek Winie Kaori Intan Mahkota, dan Agoes Ganesha Rahyuda. Pengaruh ...

Nilai $Z_{\text {hitung }}$ sebesar 2,447 lebih besar dari nilai kritis 1,96 sehingga dapat disimpulkan ada pengaruh tidak langsung yang signifikan. Dalam model diketahui bahwa setelah variabel mediasi (komitmen organisasi) dimasukkan, pengaruh langsung varibel budaya organisasi terhadap kinerja karyawan tetap signifikan. Dengan demikian, hipotesis 7, yaitu Komitmen organisasional memediasi hubungan Budaya Organisasi dan Kinerja Karyawan, terdukung.

\section{SIMPULAN DAN SARAN}

Berdasarkan hasil pembahasan yang telah diuraikan pada bab sebelumnya, maka dapat disimpulkan hal-hal berikut ini

1. Kepemimpinan transformasional $\left(\mathrm{X}_{1}\right)$ terdukung berpengaruh positif dan signifikan terhadap komitmen organisasi $\left(\mathrm{Y}_{1}\right)$. Hasil ini dapat diartikan bahwa semakin baik kepemimpinan tansformasional maka komitmen organisasi semakin tinggi.

2. Budaya organisasi $\left(X_{2}\right)$ terkonfirmasi berpengaruh positif dan signifikan terhadap komitmen organisasi $\left(\mathrm{Y}_{1}\right)$. Hasil ini dapat diartikan bahwa semakin baik budaya organisasinya, semakin tinggi pula komitmen organisasinya.

3. Kepemimpinan transfomasional $\left(\mathrm{X}_{1}\right)$ juga terdukung berpengaruh positif dan signifikan pada kinerja karyawan $\left(\mathrm{Y}_{2}\right)$. Hasil ini mengindikasikan bahwa semakin baik kepemimpinan maka semakin baik pula kinerja karyawan

4. Budaya Organisasi $\left(\mathrm{X}_{2}\right)$ terkonfirmasi berpengaruh positif dan signifikan pada kinerja karyawan $\left(\mathrm{Y}_{2}\right)$. Hal ini dapat diartikan bahwa semakin baik budaya organisasinya, maka kinerja karyawan semakin baik

5. Komitmen organisasi $\left(\mathrm{Y}_{1}\right)$ berpengaruh positif dan signifikan pada kinerja karyawan $\left(\mathrm{Y}_{2}\right)$. Hasil ini dapat diartikan bahwa bahwa semakin tinggi komitmen organisasi karyawan PT. Sasjam Riri maka semakin baik pula kinerja karyawan.

6. Komitmen organisasi terdukung sebagai variabel pemediasi secara parsial (sebagian) hubungan kepemimpinan transformasional dengan dan kinerja karyawan PT. Sasjam Riri. Hasil ini menunjukkan bahwa kepemimpinan transformasional yang semakin baik berdampak langsung pada kinerja karyawan yang semakin bagus atau dapat memperkuat komitmen organisasi karyawan, yang akhirnya mampu mendorong kinerja karyawan menjadi lebih baik. 


\section{Saran-Saran}

Setelah mempelajari semua proses penelitian yang menyangkut seluruh permasalahan yang diuji, dapat disampaikan beberapa saran sebagai berikut :

1) Perlu diperhatikan untuk pemimpin perusahaan harus selalu memberikan inspirasi dan berupaya memahami kemampuan yang dimiliki oleh karyawan untuk mengarahkan kemampuan terbaik setiap karyawannya.

2) Karyawan supaya diberikan kesempatan untuk menyampaikan ide pada setiap pertemuan diperusahaan

3) Dipandang perlu untuk meningkatkan komitmen perusahaan, supaya karyawan tidak cepat beralih keprusahaan lain apabila mereka mendapatkan tawaran yang lebih baik.

4) Perlu diperhatikan untuk peningkatan kualitas kinerja karyawan, dengan mengadakan pelatihan dan evaluasi secara rutin untuk mengurangi kesalahankesalahan yang telah karyawan perbuat dalam menyelesaikan tugas dan tanggung jawabmasing-masingkaryawan

\section{REFERENSI}

Acar, A. Zafer. 2012. Organizational culture, leadership styles and organizational commitment in Turkish logistics industry. Procedia - Social and Behavioral Scienced, 58, pp. 217-226.

Al-Ahmadi, Hanan. 2009. Factors affecting performance of hospital nurses in Riyadh Region, Saudi Arabia. International Journal of Health Care Quality Assurance, Vol. 22 No. 1, pp. 40 -54.

Bappenas, Badan Penyelenggara Pembangunan Nasional (ID). 2015. Narasi pemberdayaan koperasi dan usaha mikro, kecil, dan menengah. dikutip pada 2014 Maret 15. Tersedia pada: http://www.bappenas.go.id/ files/9013/5039/6528/bab-19narasi-pemberdayaan-ukmk.doc

Bass, B. m., \& Riggio, E. R. 2012. Second Edition. Transformational Leadership. Lawrence Erlbaum Asscociates, Publishers, Mahwah, New Jersey.

Ben, Camilus Bassey, 2012. Leadership among Secondary School Agricultural Science Teachers and Their Job Performance in Akwa Ibom State, Nigeria Agricultural Education Unit, Departemen of Vocational and Special Education. World Journal of Education. Vol. 2, No. 1.pp. 16-24. 
Ni Kadek Winie Kaori Intan Mahkota, dan Agoes Ganesha Rahyuda. Pengaruh ...

Borrill, Carol S.M.A. West \& J.F.Dawson. 2008. The Relationship between leadership and Trust Performance. Aston Buiness School Aston University Birmingham B4 7 ET.

Brown, Barbara. 2013. Employees Organizational Commitment and Their Perception of Supervisors' Relations-Oriented and Task-Oriented Leadership Behaviors. Dissertation submitted to the Faculty of the Virginia Polytechnic Institute and State University.

Chen, Li Yueh. 2009. Examining The Effect Of Organization Culture And Leadership Behaviors on Organizational Commitment, Job Satisfaction, Adan Job Performance at Small And Middle-Sized Firma Of Taiwan. Journal of American Academy of Bussiness, pp. 432-438.

Dinas Koperasi, UMKM, Perindustrian dan Perdagangan Prov Bali. 2016. Informasi Umum Masyarakat Ekonomi ASEAN. Bali.

Dessler, G., 2006. Manajemen Personalia. Terjemahan. Edisi Ketiga. Jakarta: Erlangga.

Flamholtz, E., 2015. Differential Impact of Cultural Elements on Financial Performance. European Management Journal, (23): pp. 50-64.

Furtwengler, Dale. 2007. Ten Minute Guide To Performance Appraisals, Edisi Bahasa Indonesia, Yogyakarta : Andi.

Handoko, T. Hani. 2013. Manajemen personalia dan sumberdaya Manusia.Yogyakarta: BPPE.

Huei, Jeng Chou. 2012. Effects of Paternalictic Leadership on Job Satisfaction Regulatory Focus as the Mediator. The International Journal of Organization Innovation. Vol 4 pp. 4

Jui, Chen Chen. 2009. Leadership Effectiveness, Leadership style and employee readiness. Leadership and Organization Development Journal. Vol 26 No.4, pp.280-288.

Kementerian Koperasi dan Usaha Kecil dan Menengah Republik Indonesia, 2015. Sandingan Data UMKM 2012-2015

Kreitner dan Kinichi. 2010. Organization Behavior. Irwin. Mc Graw-Hill, Boston.

Kompas, 26 Juni 2014. UMKM Menopang Perekonomian Indonesia, hal.12

Locander, W.B., F. Hamilton, D. Ladik \& J. Stuart .2012. Developing a leadershiprich culture: The missing link to creating a market-focused organization. Journal of Market-Focused Management. Vol. 5, pp. 149-163. 
Lok, Peter dan Crowford, John. 2009. The Effect of Organizational Culture and Leadership Styleon Job Satisfaction and Organizational Commitment. The Journal of Management Development Vol. 23. pp. 321-337.

Mangkunegara, A. A. Abwar Prabu. 2007, Evaluasi Kerja SDM. Bandung: PT. Refika Aditama.

Mathis Robert L. dan Jackson John H. 2006, Human Resource Management, alih bahasa. Salemba Empat. Jakarta.

Mawar. 2007. Pengaruh Kompensasi, Pelatihan, Kepemimpinan dan Lingkungan Kerja terhadap Kinerja Pegawai PT. Askes (persero) kantor cabang Denpasar. Tesis Magister Manajemen Universitas Udayana.

Meyer, J.P, Allen N.J., and Smith C.A 2013. Commitment Organizational and Occupations: Extension and Tes of Three Component Conceptualization. Journal of Applied Psychology. pp. 538-551.

Mowday, R.T, Porter, L.W dan Steers R.M.2012. Employee Organization Lingkages: The Psychology of Commitment, Absenteeism and Turnover. London: Academic Press Inc

Mondiani, Tria. 2012. Pengaruh Kepemimpinan Transformasional dan Kompensasi terhadap Kinerja Karyawan PT. PLN (Persero) UPJ Semarang, Jurnal Administrasi Bisnis, Vol 1, No 1.

Moon, M. Jae. 2010. Organizational Commitment Revisited in New Public Management (Motivation, Organizational, Culture, Sector and Manajerial Level, Public Performance \& Management Review, Vol. 24 No.2, pp.177194.

Robbins, Stephen P dan Timothy A. Judge. 2008. Perilaku Organisasi. Jakarta: Salemba Empat.

Robbins, Stephen P.2008. Perilaku Organisasi: Konsep, Kontroversi, Aplikasi, Versi Bahasa Indonesia. Edisi Dua Belas. Jakarta: PT. Prehalindo.

Safaria dan Saputra, 2009. Manajemen Emosi. Yogyakarta: Bumi Aksara

Schein, E. H. 2009. Organizational Culture and Leadership. San Francisco: Jossey-Bass

Sedarmayanti. 2007. Manajemen Sumber Daya Manusia : Reformasi Birokrasi dan manajemen Pegawai Negeri Sipil. Bandung : PT. Refika Aditama.

Siagian, P.S. 2005. Manajemen Sumber Daya Manusia, Jakarta: Bumi Aksara. 
Ni Kadek Winie Kaori Intan Mahkota, dan Agoes Ganesha Rahyuda. Pengaruh ...

Siders. 2011. The Relationship of Internal and External Commitment Foci to Objective Job Performance Measures. Journal Academy of Management June 1, 2011 vol. 44 no.3 570-579

Somers, M.J. dan Birnbaum, Dee. 2015. Work-Related Commitment and Job Performance: It's Also The Nature of The Performance That Counts. Journal of Organizational Behavior : 621-634

Sukanada, I Nyoman. 2010. Pengaruh Kepemimpinan dan Kompensasi Terhadap Disiplin Karyawaan PDAM Kabupaten Badung. Tesis. Program Pasca Sarjana Universitas Udayana. Denpasar.

Suluh Indonesia, 3 Pebruari 2015, Peranan UMKM, hal. 8

Wood, Jack M, 2011. Organizational Behaviour: A Global perspective 2nd Editon. Australia: John Wiley and Sons Australia, Ltd.

Yukl, Gary A. 2005. Kepemimpinan dalam Organisasi. Edisi Indonesia, Prenhelindo, Jakarta. 